\title{
An Initial Archaeological Assessment of Area Proposed for Modification at Fort McIntosh, Webb County, Texas
}

James E. Ivey

Thomas Medlin

Jack D. Eaton

Follow this and additional works at: https://scholarworks.sfasu.edu/ita

Part of the American Material Culture Commons, Archaeological Anthropology Commons, Environmental Studies Commons, Other American Studies Commons, Other Arts and Humanities Commons, Other History of Art, Architecture, and Archaeology Commons, and the United States History Commons

Tell us how this article helped you.

This Article is brought to you for free and open access by the Center for Regional Heritage Research at SFA ScholarWorks. It has been accepted for inclusion in Index of Texas Archaeology: Open Access Gray Literature from the Lone Star State by an authorized editor of SFA ScholarWorks. For more information, please contact cdsscholarworks@sfasu.edu. 


\section{An Initial Archaeological Assessment of Area Proposed for Modification at Fort McIntosh, Webb County, Texas}

\section{Creative Commons License}

\section{(c) (1) (8)}

This work is licensed under a Creative Commons Attribution-NonCommercial 4.0 International License 
AN INITIAL ARCHAEOLOGICAL ASSESSMENT OF AREAS PROPOSED FOR MODIFICATION AT FORT McINTOSH, WEBB COUNTY, TEXAS

\author{
James E. Ivey, Thomas Medlin, \\ and Jack D. Eaton
}

Center for Archaeological Research

The University of Texas at San Antonio

Archaeological Survey Report, No. 32

1977

TISE - center for Archaelogical Researoh 
AN INITIAI ARCHAEOLOGICAL ASSESSMENT OF AREAS PROPOSED FOR MODIFICATION AT FORT MCINTOSH, WEBB COUNTY, TEXAS

James E. Ivey, Thomas Medlin, and Jack D. Eaton

Center for Archaeological Research The University of Texas at San Antonio Archaeological Survey Report, No. 32 
TABLE OF CONTENTS

PAGE

PREFACE

ii

INTRODUCTION

1

HISTORICAI BACKGROUND

1

THE SURVEY

THE ARTIFACTS

ARTIFACTS

CONCLUSIONS

15

RECOMMENDATIONS

18

REFERENCES CITED

19

LIST OF FIGURES

FIGURE

PAGE

1. Ground Plan of Fort McIntosh and Laredo Junior College

2. Fort McIntosh Later Fort Stables and Complex

3. Fort McIntosh 
PREFACE

Historic Fort McIntosh lies on the bank of the Rio Grande within the city limits of Laredo, Texas. Situated on elevated terrain just north of where the Rio Grande makes a sharp turn east, the fort commands a strategic position on the U.S.-Mexican border.

Originally founded in 1849, Fort McIntosh served as an important frontier military post, with some periods of non-use, until it was officially closed as a U.S. Army establishment in 1949. During its one hundred years as an Army Post, Fort McIntosh served as home for both Union and Confederate troops, and was at various times under the command of officers, such as Lt. Col. Robert $E$. Lee, who would later gain national fame.

Fort McIntosh lies within the Old Fort McIntosh Historic District. Presently the Laredo Junior College occupies the site of the 01d Fort, and many of the post buildings are still standing and in use.

In November, 1976, Dr. Domingo Arechiga, President of the Laredo Junior College, contacted the Center for Archaeological Research regarding an archaeological survey of an unused open area of the college campus lying between the college buildings and the Rio Grande. Plans were under way to develop that area for athletic facilities during the following summer. In April, 1977, archaeologists from the Center visited Fort McIntosh and conducted the required survey. The results of that survey, combined with a relevant historic background and recommendations, are presented here.

Jack D. Eaton

Research Associate 


\section{INTRODUCTION}

From April 4 to 11, 1977, archaeologists from The University of Texas at San Antonio, Center for Archaeological Research, visited the site of Fort McIntosh (41 WB 11), presently occupied by the Laredo Junior College, Laredo, Texas.

The purpose of the visit was to conduct four days of on-the-ground survey and limited testing in the southwestern area of the Fort Site where construction of college athletic facilities is planned. This area lies between the college campus and the bank of the Rio Grande. The survey was designed to determine, if possible, what archaeological and historical resources remain in the proposed development area (Fig. 1).

The survey was conducted under formal contract between the Laredo Junior College (Dr. Domingo Arechiga, President) and The University of Texas at San Antonio, Center for Archaeological Research. Fieldwork was done under the supervision of Dr. Thomas R. Hester, Center Director, and Mr. Jack D. Eaton, Research Associate.

The field crew consisted of James Ivey, crew chief and archaeologist, and Thomas Medlin, crew member and military historian. The archaeological assessment began by a surface survey of the area proposed for modification. The survey team searched for surface artifacts, noted zones of artifact concentrations, and recorded structural remains and road traces. Artifacts were collected and bagged separately according to defined areas, and traces of structural remains, when observed, were noted for possible subsurface testing.

To aid in an understanding of what was found during the survey, and to support the interpretations of those finds, a brief outline of the history of Fort McIntosh is provided. This is followed by a description of the collected artifacts and structural remains noted. The results of subsurface testing are presented, and an assessment of the archaeological situation, based upon the field studies and literary research, is given. Finally, conclusions and recommendations are presented.

\section{HISTORICAL BACKGROUND}

The history of the establishment and activities of Fort McIntosh has been given in detail elsewhere (cf. Thompson 1973, 1974, and Wilkinson 1975). Our concern here is with those details available in these histories which give us information about what we can expect to see in the ground.

The fort was officially established as Camp Crawford on March 3, 1849, and renamed Fort McIntosh on January 7, 1850 (Thompson 1974:165,166). For the first few years quarters consisted largely of tents, but by 1853 some solid structures had been erected (Fig. 3). In July of that year Captain W. G. Freeman inspected the post and found six wooden-frame and two stone-built structures. The frame buildings included a hospital, two company quarters, 
two officers' quarters, and a storehouse. These structures were originally built to be the kitchens for planned larger buildings not yet constructed. The two stone buildings comprized the guardhouse and magazine (Crimmins 1950:204).

In October and November of 1853, Major Richard Delafield surveyed the entire post and prepared a detailed map of the existing structures and the plan of the proposed Star Fort north of the occupied area. The fort was to assume the name Fort McIntosh, while the present area of occupation was called Cantonment McIntosh. Delafield's map shows that to the group of eight structures present in July, another 14 had been added. These consisted, for the most part, of very small shacks serving as kitchens for the larger structures. It will be recalled that the larger structures had themselves been intended as kitchens for even larger structures. The largest structures were never built. Included in the 14 new buildings were a sutler's shop, blacksmith shop, bakery, carpenter's shop, and two stable buildings (National Archives 1853).

In 1856, Colonel J. K. F. Mansfield inspected the post and found few changes. The Star Fort was complete, and the plan of the cantonment was unchanged except for a few added buildings. These included several tent structures around the hospital, the combining of the bakery, blacksmith shop, and carpentry shop into one new structure, the construction of a new officers' quarters, and the conversion of the old company quarters to additional officers' quarters. At the time of the Mansfield inspection there were four companies of infantry, two companies of mounted rifles, and one company of artillery stationed at the post. All enlisted and non-commissioned personnel lived in tents. The mounted rifles' camp was apparently in the general area of the Later Fort stables complex. The five officers' quarters housed most of the 13 officers assigned to the post at that time (Crimmins 1939:228-239).

A description of some of the post buildings in 1856 is available to us in the letters of Captain Randolph B. Marcy, then post commander of Fort McIntosh. Some of the buildings were described as unfloored, without glass windows, and having cloth roofs and doors. Marcy's quarters, probably half of a "duplex," consisted of a parlor and bedroom, apparently connected by a short hall. The building had a wooden floor and a fireplace with a mantelpiece (Thompson 1974:184).

When the fort and cantonment were abandoned in March of 1859, there were 30 buildings of sufficient note to be sold at public auction. These were probably moved off the post area (Thompson 1974:187).

The fort was reoccupied in February of 1860 during the period of the raids carried out by Juan Cortina, and continued in occupation until the secession of Texas from the Union. On March 12, 1861, the fort was again abandoned (Thompson 1974:189,192). No indication is given of any construction during this period. 
Fort McIntosh was reoccupied after the Civil War, on October 23, 1865 (Thompson 1974:216). The new garrison lived in tents for the first few years, as before, and began construction of a new fort. By late 1872, when the post was inspected by Colonel Edmund Schriver, the buildings consisted of a guardhouse, storehouse, a hospital of stone, a corral, small officers' quarters of adobe, and a stable built of timber (Conway 1963:571). By 1875 a second corral with a blacksmith's shop, several haysheds and storehouses, a bakery, a laundress' quarters, and a small headquarters building, the last two of adobe, had been added (U.S. Army 1876:202-203).

The use of brick for post buildings apparently began around 1880, and most or all of the Later Fort buildings are of yellow Laredo brick. By 1897 the Later Fort had grown to include at least 40 buildings (Koehler 1897).

After 1900 there were two major build-ups of the post during the two world wars, with subsequent dismantling of the new structures. The fort was officially closed as an Army post in 1946, but continues in limited use by the National Guard and U.S. Army Reserve units, which still have an operating establishment there.

The construction of the Later Fort and the added buildings and land modifications of the twentieth century directly affected the area of the Early Fort. A reconstruction of the combined plans of the two forts shows that the post garden of the 1890's was placed on the parade ground of the Early Fort, and perhaps obliterated the Early Fort magazine. The two rows of buildings on the north side of the Later Fort parade ground crossed the officers' quarters complex of the Early Fort and may have destroyed some of their remains. WPA work in the $1930^{\prime} \mathrm{s}$ involved the construction of a drainage ditch across the westem side of the Later Fort grounds, and also cut through the area of the Early Fort stables, guardhouse, and storehouse. Later roads and housing in the twentieth century have undoubtedly further damaged the traces of Early Fort structures in the ground.

It is likely, however, that remnants of these structures still survive. If any subsurface features remaining could be accurately relocated, perhaps this type of valuable information could be saved.

\section{THE SURVEY}

Surface Examinations: The areas to be affected by construction were examined by a walk-over surface survey, and collections were made of representative artifacts.

The southwestem area of the fort compound was surveyed in one continuous operation (Area A) (see Fig. 1). Although randomly scattered objects were found during this examination, two major concentrations of surface materials were noted. The first, and by far the largest concentration appears to have been the dump area of the Later Fort. It is being exposed by vehicle use and erosion in the dirt road along the north side of the south compoind 
Figure 1. Ground Plan of Fort McIntosh and Laredo Junion College. Indicated are artifact collection zones in the surveyed area where athletic facilities are planned. 


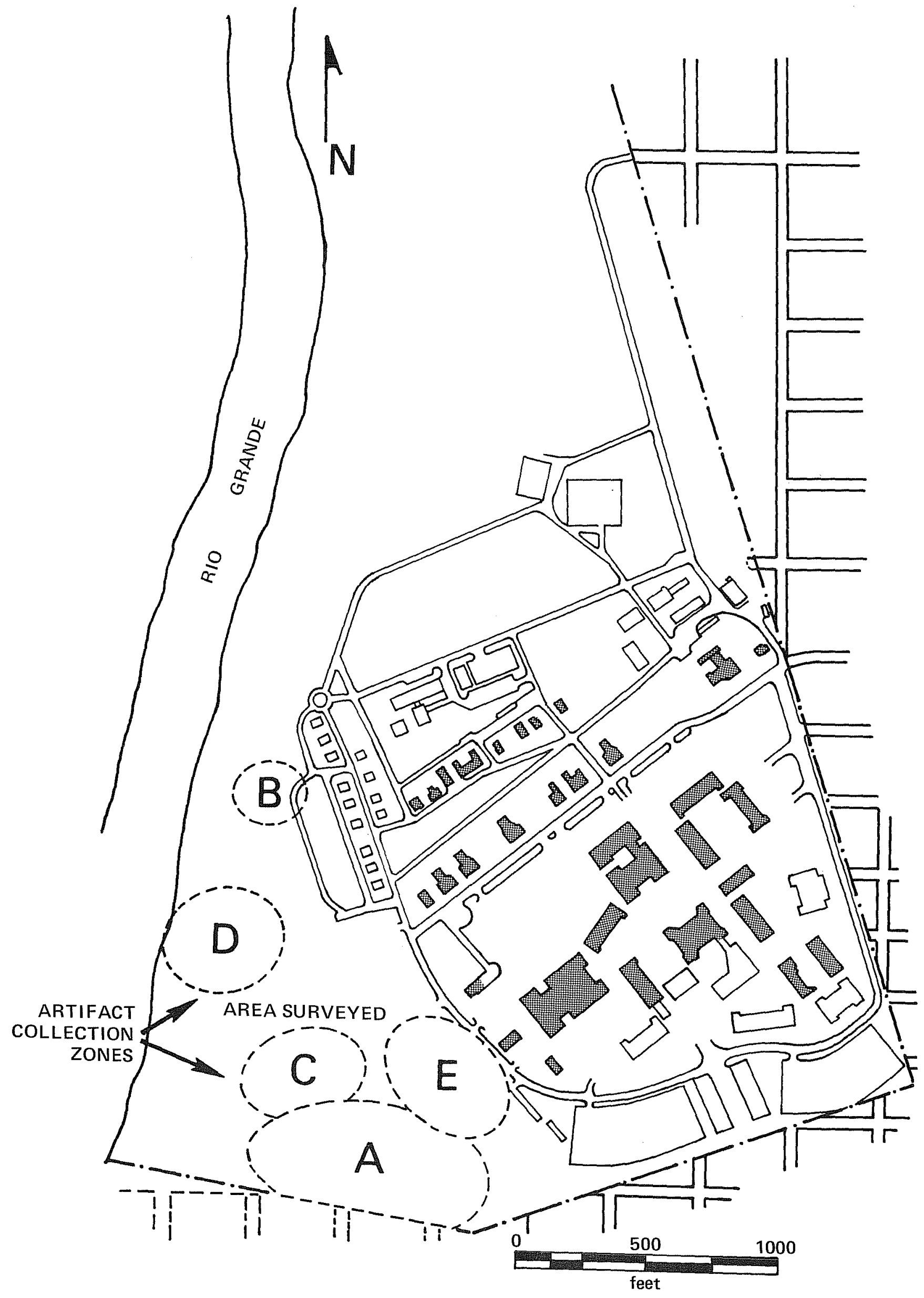


wal1, about 750 feet east of the bank of the Rio Grande. A second and considerably smaller concentration was found along an older road trace which came from the central regions of the Later Fort and descended the bank of the Rio Grande about 250 feet north of the south compound wall.

After a period of intensive map studies, an attempt was made to locate traces of the Early Fort in the region of areas $B, C$, and D (Fig. 1 ). A small concentration of artifacts was found in the north Early Fort area (Area B), where the maps indicated the original hospital was 1ocated. A second concentration was found in the approximate area of the original stables, guardhouse, sutler's shop, and the southern Early Fort area (Area C). A few artifacts were also found in the central Early Fort area (Area D).

In the region of the Later Fort stables (Area E) no particular concentration of artifacts was found, but this was expected since the area had been scraped by bulldozer. A foundation trace was found in Area F, corresponding to the location of the gunshop as indicated on the Koehler map (1897). No artifacts were found in this area.

Subsurface Testing: Because of the limited time available, testing was carried out only in the Later Fort stables area. Testing was originally considered for the Later Fort dump and Later Fort gunshop area, and to verify certain estimated positions of Early Fort structures. These considerations were, however, set aside. In the case of the dump area and the gunshop, the presence of remains was self-evident. It was felt that the limited time could be better used testing in an area of less certainty. An attempt to locate an Early Fort building by testing would appear to have been well worth the effort; however, when the testing phase began, it was realized that to verify the plan of the Early Fort on the ground by subsurface trenching, without surface indications, would be a task too great to attempt on a preliminary survey. The stables area of the Later Fort was known to have had other buildings besides those still standing, and the locations of these buildings were known with fair accuracy. It was concluded that a test in this area, at a point of reasonable certainty of the presence of a structure, would give us valuable information about the survival of structural remains in the ground where no surface indications, or even artifact concentrations, were evident.

Using the Koehler map of 1897 we were able to estimate with fair accuracy the location of a complex of sheds and stables around those brick structures still standing in the stables area (see Fig. 2). The structure considered to be the most accurately located was the northeastward extension of the "granary and hayshed" structure. Here the first 60 feet still stood in the form of a long brick building north of the Multimedia Center. It was decided that the brick structure had been the "granary" section of the building, and that the "hayshed" had been a long pole-and-roof structure, largely open to the air. It was therefore expected that the structural traces to be found would be in the form of floors and postmolds, with accompanying artifacts. A series of test excavations of limited size and 
depth (about $50 \mathrm{~cm}$ by $50 \mathrm{~cm}$ and less than $20 \mathrm{~cm}$ deep) were carried out in order to search for traces of this structure. Two pits were placed along the north end of the "granary" and against the wall. One was placed at the northwest comer of the brick structure, and one at the center of its north end wall. Both revealed the stumps of posts still in place in the ground, and a considerable quantity of artifacts. The centerline post was about $18 \mathrm{~cm}$ in diameter and appeared to be of cedar. Several square nails were still protruding from its surface. The northwest comer post was about $10 \mathrm{~cm}$ in diameter, and also appeared to be cedar. Indications of a hard earth surface were noted around the posts at a depth of about $12 \mathrm{~cm}$ below the present ground surface.

A third pit was dug at about four meters from the north end of the brick "granary" and centered on the probable line of the west face of the "hayshed." This soon revealed a hard, thin layer of gravel at a depth of about $11 \mathrm{~cm}$. The layer was about $1.5 \mathrm{~cm}$ thick, and a few artifacts were found in the gravel.

The fourth area excavated was about eight meters from the north end of the "granary" on the probable centerline of the "hayshed." This revealed a continuation of the gravel "floor." No artifacts were found in this test.

The fifth test was made on the probable west face of the "shed," about 12 meters from the north end of the "granary." This test uncovered no gravel, but a clearly defined hard-packed light tan earth surface was encountered at a depth of approximately nine $\mathrm{cm}$. This lay below $1.5 \mathrm{~cm}$ of softer, grayer earth. This upper level gray earth contained a number of metallic and other artifacts.

A final test was made 24 meters from the north end of the granary on the Iine of the probable west face of the shed, and again revealed a hardpacked earth surface at a depth of about $13 \mathrm{~cm}$. No artifacts were found in this limited area test.

\section{THE ARTIFACTS}

The artifacts collected during the initial assessment of the proposed development zone at Fort McIntosh are listed below. Collection proveniences are related to five vaguely defined areas (Areas $A-E$ ) in the study zone as noted in Fig. 1.

The artifacts are listed according to the area in which they were found. They are presented in categories (metal, ceramic, etc.) and include quantities collected. The artifacts collected from Areas A through D are surface finds. In Area $E$, the artifacts were collected from five test excavations (Fig.2). 
Figure 2. Fort McIntosh Later Fort Stables Complex. Indicated are standing structures, positions of 1897 Fort structures now gone, and locations of test pits excavated. 


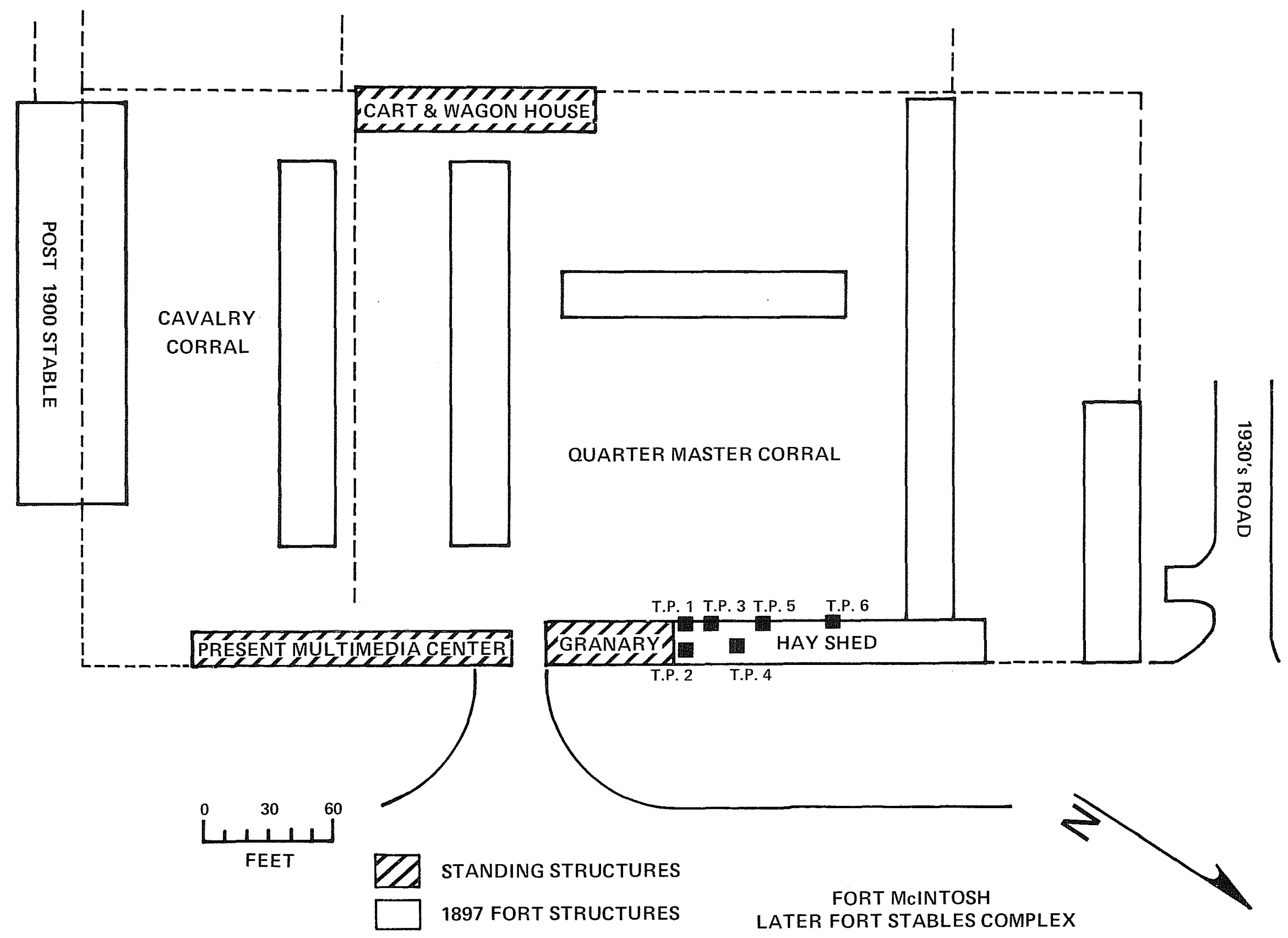


Presented here is a listing of the artifacts. It is not, of course, a comprehensive analysis, but serves to aid in the interpretations of past events and structural activities relating to Fort McIntosh. It also demonstrates the quantity and kinds of interpretive materials which are available in the study zones.

\section{ARTIFACTS}

Surface Survey

AREA A

Meta1

1 U. S. Army Hospital Corps Officer's insignia-also known as "Geneva Cross". 1896-1901

(Samuel Nesmith, Institute of Texas Cultures, personal communication).

1 round can with soldered filler-hole seal-condensed milk or baking soda can.

2 cartridge cases, 7.62 mm NATO blank rounds.

1 bullet, .45 caliber. Steel jacket, lead core.

2 square nails.

3 wire nails.

1 chain link.

1 flat hook. Steel bar stock with electric arc welding on one edge.

1 unidentified steel object.

Ceramics*

Porcelain

2 clear glaze, hand-painted in gold, red, brown, green

* These sherds are from approximately five types of vessels, including plates, bowls, pitchers, and large tureen-like containers. 
Ironstone

7 clear glazed base sherds. One with mark "K.T.\&..." This is mark of Knowles, Taylor, and Knowles, post1872 (Kovel 1953:78). Overprinted with mark

"Q.M..." in blue ink. This is mark of U.S. Army Quartermaster.

28 body sherds, one with molded floral decoration.

14 rim sherds, one with molded floral decoration.

I clear glazed body sherd, with black and brown bands.

Earthenware

1 majolica. No decorations on sherd.

7 clear glazed, white paste, two with blue and green decorations.

I clear glazed, white paste, with hand-painted floral destgn in green, black and red.

2 yellow glaze, tan paste.

1 tan glaze, tan paste, brown interior slip.

\section{Glass}

1 window glass fragment.

Containers: Clear

14 body fragments.

1 body fragment, flat, from square bottle.

5 basal fragments, one marked "15 (I) 72 ".

Mark of Owens Illinois Glass Company, post-1954

(Toulouse 1972).

1 neck and Iip fragment. Post-1870 (Toulouse 1972).

Containers: White

1 body fragment.

Containers: Green

8 body fragments.

Containers: Aqua

1 body fragment.

1 Iip fragment. Post-1870 (Toulouse 1972). 


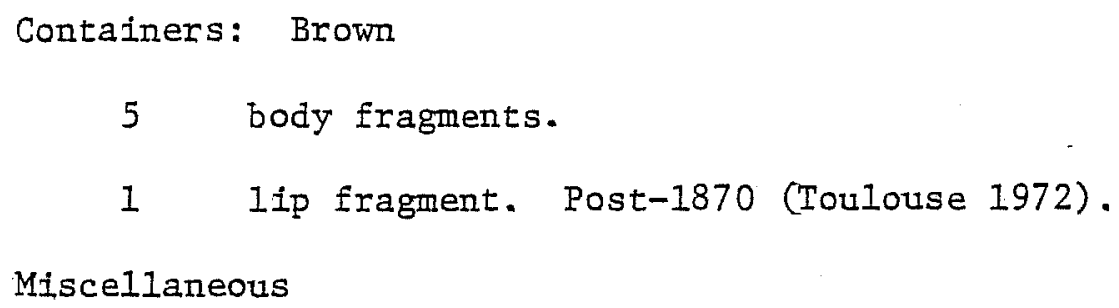

AREA B

\section{Glass}

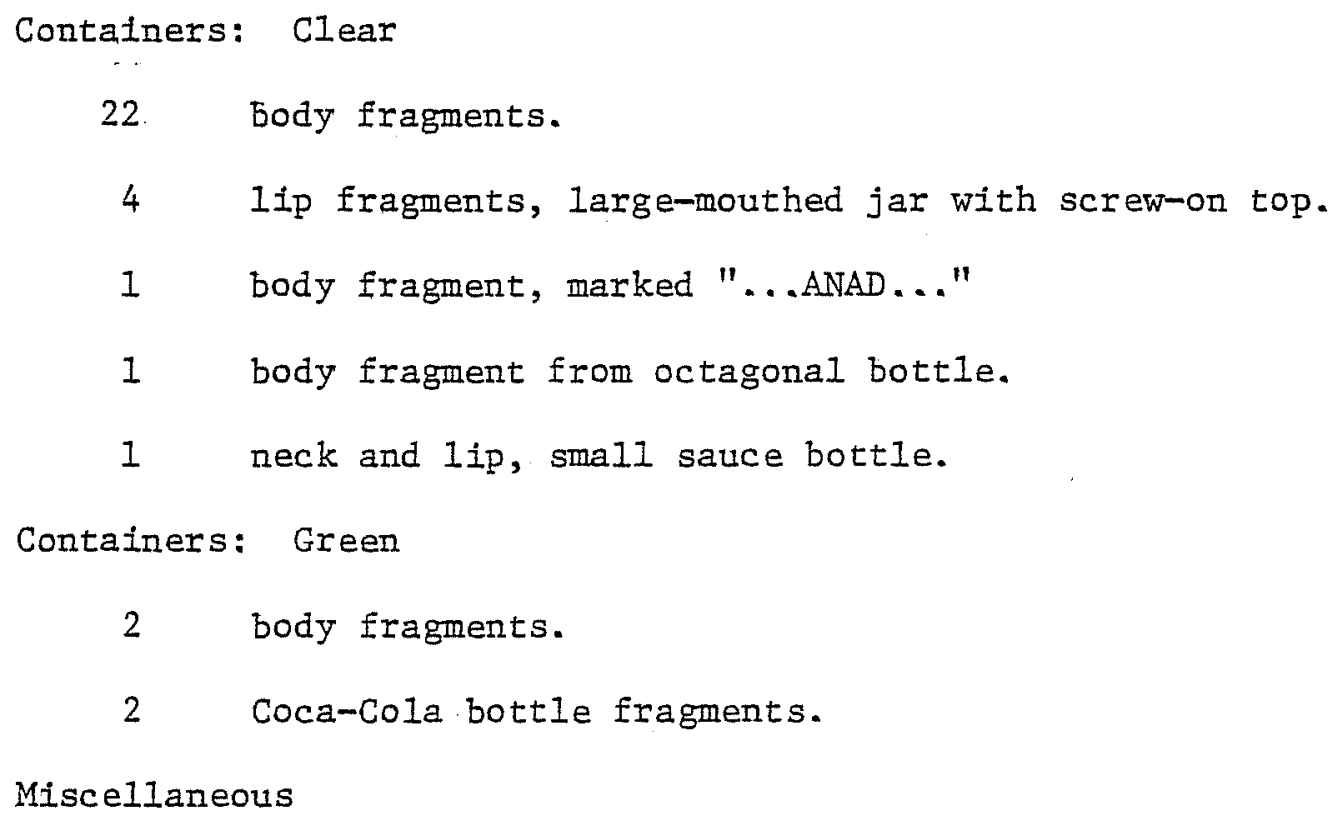

1 fragment of ceramic electric screw-in fuse.

AREA C

Meta1

1.410 caliber shotgun shel1 base, post-1900.

1.22 caliber bullet, lead, post-1900. 
1 fragment lead bar, pincer-cut at both ends.

1 cast iron stove fragment.

1 woodscrew, flathead.

2 square nails.

2 unidentifiable iron fragments.

1 large hinge, formed from bar stock (probably a gate hinge).

Ceramics

Porcelain

2 clear glaze; one is a rim sherd.

2 porcelain dol1 sherds. Post-1870. (Hume 1970:317318).

Ironstone

1 clear glazed rim sherd.

1 clear glaze with brown floral transfer, on interior.

Earthenware

19 clear glaze, white paste.

1 unglazed, red paste.

1 salt-glazed with brown paste, tan interior slip.

1 clay pipe stem fragment.

Glass

14 window glass fragments.

Containers: Clear

16 body fragments.

1 base fragment from square bottle.

1 bod̄y fragment, marked "...EACT..." 


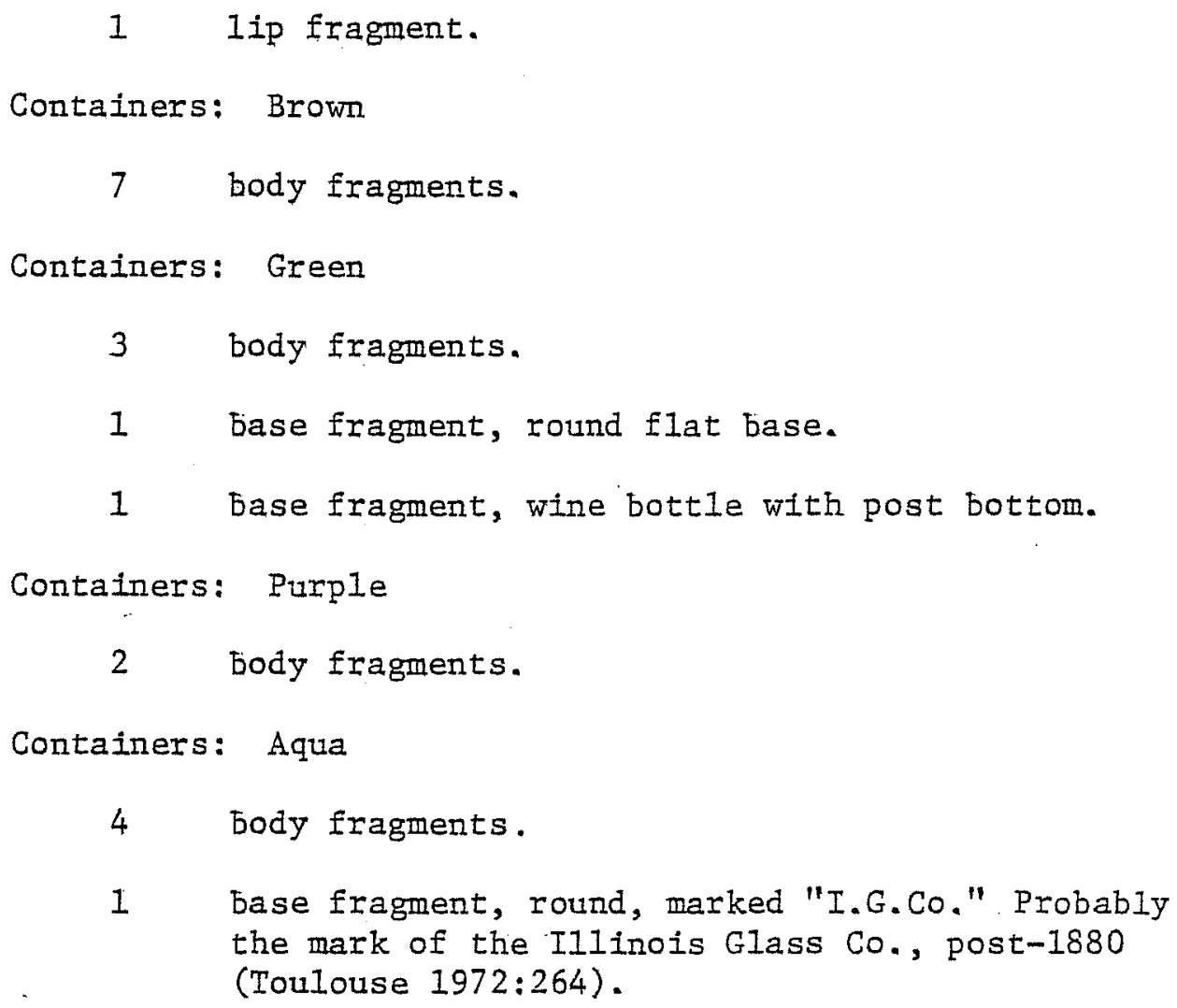

Miscellaneous

4 pieces sandy plaster with a tan-yellow painted surface. Two pieces have fragments of a coarse red sandstone adhering.

4 pieces window putty.

AREA D

Meta1

1 .30-06 blank cartridge case.

1.22 caliber cartridge case.

1. .22 caliber bullet, lead.

1 square nail.

1 wire nail.

1 button back, apparently military. 


\section{Ceramics}

Ironstone

1 clear glaze.

6 clear glaze with Blue Willow transfer print:

Earthenware

1 clear glaze, white paste.

Glass

$\begin{array}{cl}1 & \text { marble. } \\ 8 & \text { window glass fragments. } \\ \text { Containers: } & \text { Clear } \\ 6 & \text { body fragments. } \\ 1 & \text { base fragment. } \\ 2 & \text { lip fragments. }\end{array}$

Containers: Brown

3 body fragments.

Miscellaneous

1 piece ceramic insulating tube with triangular hole.

Subsurface Tests

AREA E, TEST PITS 非 AND 非

MetaI

2 wire nails.

1 wire nail with lead collar. Roofing nail.

1 square nail.

2 small tacks (possibly saddle construction tacks).

9 can fragments. 
TEST PIT $\# 3$

Metal

5 wire nails, of which 3 are roofing nails.

1 square nail.

3 horseshoe natls.

1 lead washer.

1 steel wire fragment:

1 fragment copper wire with rubber insulation.

1 brass buckle. Probably harness buckle.

1 Iiberty Head nickel; date 1887 (last digit uncertain). Note: Thts coin is unusual in that it seems to have been given a thin brass coating to make it appear to be a flve-dollar gold piece. The practice of altering this type of coin in such a manner is discussed in Yeoman (1967:93).

Bone

1 fragment long bone, probably bovine or equine.

TEST PIT \#4

No artifacts.

TEST PIT \#5

Meta1

$$
\begin{aligned}
& 1 \text { bottle cap. } \\
& 2 \text { wire nails. } \\
& 3 \text { pieces steel wire. } \\
& 2 \text { square nails. } \\
& 1 \text { brass washer for saddle construction. } \\
& 1 \text { brass nail for saddle construction. } \\
& 2 \quad \text { fragments of copper tubing. } \\
& 14 \text { pieces of rusty iron, unidentifiable. }
\end{aligned}
$$


Glass

Containers: Clear

1 body fragment.

Containers: Green

5 body fragments.

TEST PIT 非

No artifacts.

\section{CONCLUSIONS}

No indications of any prehistoric occupation of the area were found, although it is quite possible that such evidence could exist under more recent alluvial depositions near the river.

The present survey located a quantity of historic artifacts, and analysis has shown that none can be considered to date before 1860. It would appear that only debris from the Later Fort has been located, and that material from the Early Fort was not observed. This seems to be a function of sampling, as Early Fort subsurface remains are expected to exist.

Subsurface testing, combined with discussions with local informants, has given a reasonable explanation for this situation. Occasionally the Rio Grande will flood to a sufficient height to cover these areas with water, and such an inundation usually deposits a layer of alluvium. In the area of the Later Fort stables, testing has uncovered surfaces which were in active use as of 1897. These lay below the present surface, under 10-12 cm of silt. This does not allow for subsequent removal of an undetermined amount of overburden by bulldozer. The pre-1860's material could well be under 25 cm or more of overburden.

The early Fort (Fig. 3) consisted of a compound of wooden-frame structures, many roofed in canvas, and a few with plate glass windows. Some had wooden floors, but many did not. In association with some of these woodenframe structures were semipermanent tent structures, possibly consisting of a wood-frame covered with canvas. A few adobe structures were built, but these have not been indentified in the group of structures. At least two structures in the cantonment area were built of stone: the magazine and the guardhouse. Stone was probably used to some extent as foundation supports for some of the wooden-frame structures, specifically those with floors. The ground plan, and size, shape and function of many of the structures during the Early Fort period can be determined from Delafield's map (1853). Unfortunately, it is not at present possible to accurately locate Delafield's plan on the ground. 
Figure 3. Fort McIntosh. Approximation of Combined Plans of Early Fort (1853) and Later Fort (1897). Shown in overlay is the planned athletic facility. 


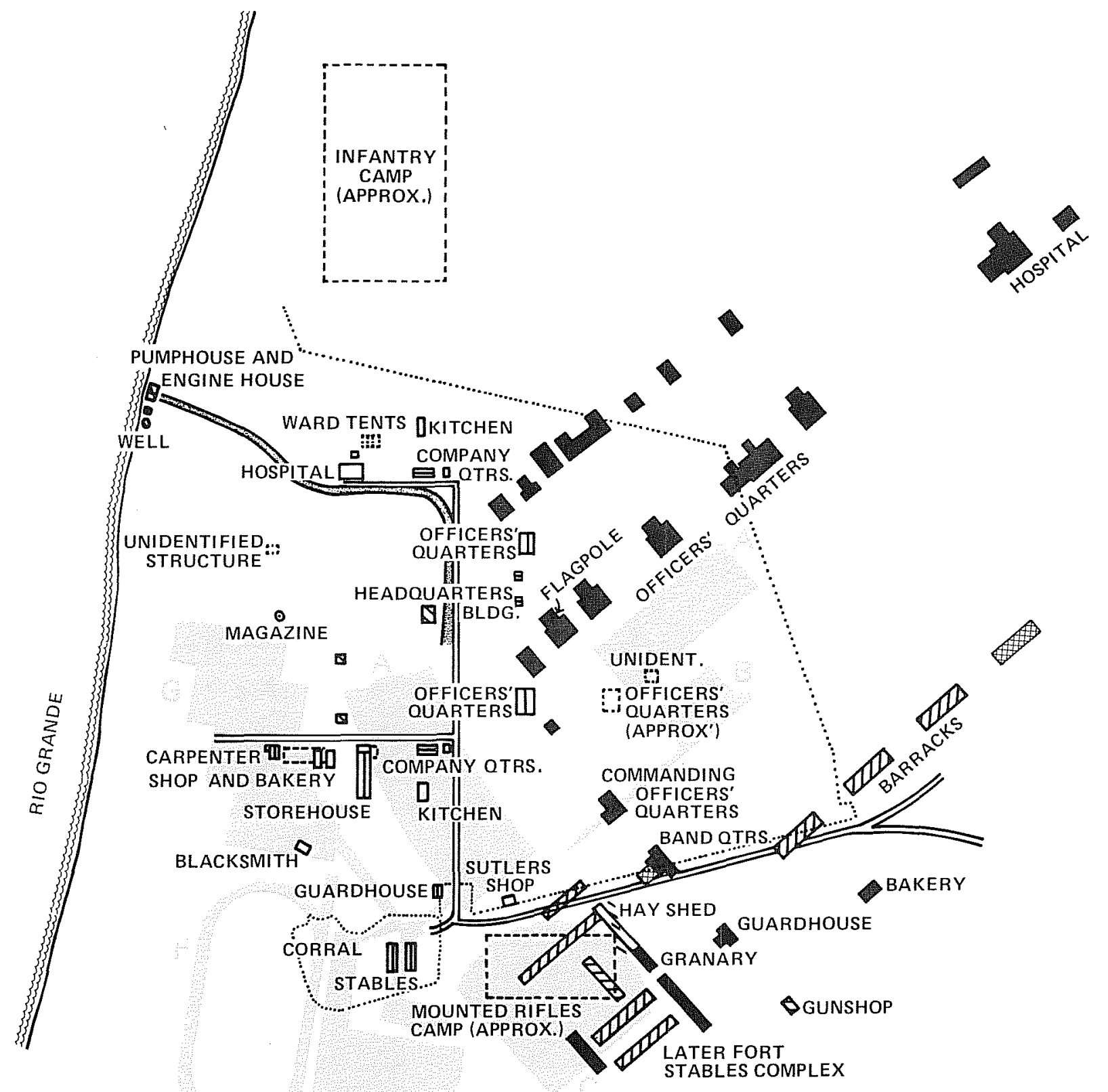

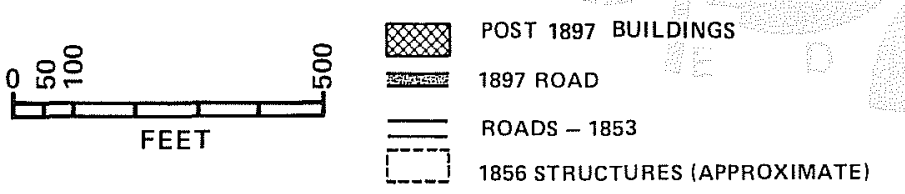

BUILDINGS - 1853

LATER FORT STANDING STRUCTURES ZZ1
FORT McINTOSH

APPROXIMATION OF COMBINED PLANS OF EARLY FORT (1853) AND LATER FORT (1897) 
Archaeological traces will, in most cases, consist of a concentration of artifacts with a strong Army association dating from the period 18491859. In many cases postholes could be evident. Most artifacts will probably be under perhaps as much as $20 \mathrm{~cm}$ of tan silty soil--perhaps even deeper. It will be necessary to make an estimate of the probable position of the plan on the ground, and to undertake a series of test pits to locate the remains of at least one of the structures accurately. From this the remainder can probably be plotted with good accuracy. The magazine and guardhouse will probably still have traces of stone foundations in the ground.

The 1856 officers' quarters, which were located somewhere in the northwest comer of the Later Fort's parade ground (see Fig. 3), were probably destroyed by the roads and the old fountain in that area. No indications of this site were seen on the ground. The mounted rifles' camp of 1856 may have left some subsurface traces in the area of the Later Fort stables complex.

Disturbances of some of the structure sites is probably severe, and some in the southwest area near an arroyo may have been severely eroded. Some sites may have been affected by plowing of the Later Fort's post garden. It is, however, highly unlikely that all traces of the Early Fort are gone; it is much more likely that they are simply hidden under a silty overburden.

The Later Fort consists of two periods, at least in its more substantial buildings. Those built of stone are of the earlier Reconstruction period, while those of brick are of the later, final fort period, after 1880 . In the stables area several structures were noted with stone footings supporting brick upper walls, while others have brick footings as well as brick upper walls. It is tentatively assumed that the combination brick-and-stone structures are intermediate in date, and perhaps were built circa 1880 .

Some timber and adobe buildings were constructured, but most were early and their positions uncertain; later maps do not give construction material details. Subsurface probes have shown that, as expected, at least one of the vanished structures in the stable complex was of pole-and-roof construction; it is considered likely that most of the other structures of that complex will turn out to have been so built. A blacksmith shop is expected to have been in the stables complex. The subsurface testing has shown that there is a good chance that much of the subsurface remains of these buildings will have survived.

A foundation trace east of the stables complex was assumed to be that of the gunshop on the 1897 Koehler map. It is a stone foundation, and is therefore pre- or circa 1880. 
Subsurface testing has shown that structural remains for the most part will be close to the surface, and that the soil is reasonably easy to dig. Structural traces show up well in contrast to the light tan sandy silt of the earth. This indicates that a considerable return in information could be gained from any effort expended in excavations.

Map analysis indicates that in the area of the Later Fort's parade ground had stood the original commanding officer's quarters, headquarters building, and a laundress' house, all built of adobe and dating aroung 1875 . Our best estimate of the locations of these structures puts them under the present Library and Cafeteria-Commons. There is little chance that their remains survived the construction of these buildings. No other buildings are known to have been in the area of the Later Fort parade ground, and no artifacts were found in this zone.

\section{RECOMMENDATIONS}

As the present plans for development of athletic facilities are laid out, the baseball diamond will directly affect the subsurface remains of much of the Later Fort stables complex, and may affect the standing brick structures of that complex. Any such construction, and any modifications or restorations performed on the brick stables buildings, should be preceded by thorough investigations.

The football and soccer field will, in its southemmost sections, directly affect the Later Fort dump, which contains a valuable record of the material culture of the U.S. Army on the Texas frontier in the late nineteenth century. Some excavations should be carried out in this region. A second concentration of aritfacts was noted along an old road trace which runs through the central sections of the proposed football and soccer field. Some test excavations should perhpas be placed in zones of greatest artifact density.

The traces of the foundation of the gunshop are in an area to be affected by eventual construction, but apparently will not be directly affected by the present work. However, this structure is considered to be in an area which will suffer severely through indirect effects, since it is immediately adjacent to a road intersection, already adversely affected by traffic and parking. The heavy traffic associated with a major construction project will probably destroy this foundation and its associated archaeological information unless it is protected or mitigating excavations are carried out.

The tennis courts and nearby parking lot, the northern half of the football and soccer field, and associated bleachers and sidewalks all will directly affect the area of the south Early Fort and its associated buildings. These structures should be sought via a mapping and testing procedure, and any structures located should be excavated in detail. 
The zone in the northwest corner of the Later Fort parade ground should be briefly tested, notably in the area of greatest likelihood for the position of the 1856 officers' quarters, if this is not in a road or paved parking lot. The risk of possible failure to locate any remains should be balanced against the gains which would come from excavating an Army borderlands fort of the 1850s.

In addition, it should be pointed out that any future development affecting a known fort structure, or involving any earth-moving activities, must be, in our evaluation, accompanied by thorough archaeological investigations.

\section{REFERENCES CITED}

Conway, W. C. (editor)

1963-64 Colonel Edmund Schriver's Inspector-General's Report on Military Posts in Texas, November 1872--January 1873. Southwestern Historical Quarterly $67: 559-583$.

Crimmins, M. L. (editor)

1938-39 Colonel J. K. F. Mansfield's Report of the Inspection of the Department of Texas in 1856. Southwestern Historical Quarterly $42: 122-148,215-257,351-387$.

1947-51 W. G. Freeman's Report of the Eighth Military Department. Southwestern Historical Quarterly 51:54-58, 167-174, 252-258, 350,357 ; $52: 100-108,227-233,349,353,444-447$; $53: 71-77,202-$ $208,308-319,443-473 ; 54: 204,218$.

Hume, I, N.

1970 A Guide to Artifacts of Colonial America. Alfred A. Knopf, New York.

Kovel, R. M. and T. H. Kovel

1971

Dictionary of Marks--Pottery and Porcelain. Crown Publications, New York.

National Archives

Survey of the Cantonments and Adjacent Grounds and Plans of Fort McIntosh near Laredo on the Rio Grande, Texas. By Richard Delafield. Major of Engineers. Made in October $\&$ November, 1853. Record Group \#77, Dr. \#148-32. Washington, D.C.

Fort McIntosh, Texas. To Accompany Report of Buildings, water Systems; Etc. March 4, 1897. Drawn by Hugo Koehler. 
Record Group \#94, Records of the Adjutant General's Office, Reservation File, 1800-1916.

Thompson, J.

1973 First Flag Over Laredo; Officers Leave Blood, Mark on Laredo; Sounds From Civil War Could be Heard All the Way to Laredo; The Battle of Laredo; and Fort McIntosh Purchased for $\$ 1$. All in Laredo Times (February and March, 1973).

1974 Sabers on the Rio Grande. Presidal Press, Austin.

Toulouse, J. H.

1972 Bottle Makers and Their Marks. Thomas Nelson, Inc., New York.

U.S. Army, Corps of Engineers

1876 Outline Descriptions of the Posts in the Military Division of the Missouri. Headquarters, Military Division of the Missouri, Chicago.

Wilkinson, J. B.

1975 Laredo and Rio Grande Frontier. Jenkins Publishing Company, Austin.

Yeoman, R. S.

1967

A Guide Book of United States Coins. Whitman Publishing Company, Racine. 